\author{
V.A. Kalytka ${ }^{1}$, M.V. Korovkin ${ }^{2}$, A.I. Aliferov ${ }^{3}$, \\ A.V. Bashirov ${ }^{4}$, T.A. Khanov ${ }^{4}$, D.R. Talaspekov ${ }^{1}$ \\ ${ }^{1}$ Karaganda State Technical University, Kazakhstan; \\ ${ }^{2}$ National Research Tomsk Polytechnic University, Russia; \\ ${ }^{3}$ Novosibirsk State Technical University, Russia; \\ ${ }^{4}$ Karaganda Economic University of Kazpotrebsouz, Kazakhstan \\ (E-mail: kalytka@mail.ru)
}

\title{
Theoretical bases of the methods of modernization the cylinders of heating steam turbines
}

\begin{abstract}
The theoretical foundations of the methodology for designing and upgrading the technological schemes of the thermal steam turbines are described in the nominal operating mode, based on the theoretical temperature schedule of the heating systems and the associated loads of consumers. As a basic method of numerical optimization of the parameters of the turbine stage, the minimization method of the comparison function (MCF-method) is used, based on the search for minimum points for a multidimensional functional reflecting the relationship between the theoretical and experimental values of technical characteristics processes of the working substance (steam) moving through the elements of the stage. The construction of the mathematical model of the investigated processes is carried out on the basis of one-dimensional and two-dimensional nonlinear equations of the hydrodynamic flow and heat equations, taking into account losses at various increments at different parts of the process flow diagram. As the object of investigation adopted Heat Steam turbine model T-110-120-130 LMF operating at nominal parameters (110 MW) in a station «Karagandinskaya TPS-3». Subject of modernization consists in replacing the group of stages of rotor blades and MPC, LPC on the blades saber shape. According to the results of detailed numerical calculations, the reconstruction stages MPC provides the estimated increase thermal power turbine $10-12 \mathrm{Gcal} / \mathrm{h}$, the entire station $90-120 \mathrm{Gcal} / \mathrm{h}$, which has certain practical importance in the development of technological renovation plans TPS circuits. On blades saber shape model theoretically established nonlinear hydrodynamic effects, manifested in the form of a nonlinear function calculated relative stage efficiency of the internal steam pressure in the upper heating selection.
\end{abstract}

Keywords: thermal steam turbine (TST); basic thermal circuit (BTC); high (HPC), medium (MPC) and low (LPC) pressure cylinders; relative internal efficiency of the turbine stage; available thermal capacity of the turbine; saber shaped blades; nonlinear hydrodynamic effects.

\section{Introduction}

Technical level and indicators of technical and economic efficiency (TEI) of the operation of steam turbines and functional elements (main and auxiliary working bodies) of their technological schemes are laid, mainly at the design stage of aggregates of this class [1,2]. At the same time, modern turbine plants are striving to make wide use of innovative achievements in the field of hydrodynamics and aerodynamics, thermal physics and theoretical heat engineering, the theory of strength and reliability of machines, machine-building materials, the theory of automatic regulation and management, etc., in order to ensure the competitiveness of the equipment in modern conditions of the energy market [2,3].

Along with the design, the development of schemes and methods for reconstructing existing turboaggregates and flow parts of steam turbine cylinders is a fairly complex multi-level engineering and technical problem requiring a comprehensive solution based on detailed theoretical and experimental analysis of various turbine schemes and operating modes, depending on the initial parameters and external loads (electrical, thermal, etc.). At all stages of modernization of technological schemes, turbines must be equipped with qualitative methods that allow constructing schemes of solutions of optimization numerical problems with a certain degree of accuracy, using the apparatus of statistical theory, automatic control theory, mathematical and computer modeling. The procedure for implementing multi-level tasks is largely determined by information consistency between different levels of the design scheme. To implement this approach, it is necessary to have a series of algorithms and software for solving design problems that provide reliable data at various levels of structural detail $[4,5]$.

Perfection of mathematical models of physical phenomena (which form the basis of the technological process under investigation) and constructive forms is especially relevant in the development of generalized systems of machine design (in a certain field of technology), taking into account the nonlinear processes oc- 
curring on the elements of technological schemes in the case of variable operating modes, over a wide range variations of numerical values of technical parameters of plants [6]. In the numerical optimization and mathematical modeling of steam turbine reconstruction schemes, it is necessary to take into account that nonlinear processes (thermodynamic and hydrodynamic processes) can occur on the elements of the flowing part having a rather complex non-standard geometric shape and working in the region of critical parameter values $[7,8]$.

At the same time, special attention is paid to the development of modern directions for the creation and modernization of the equipment in question to ensure its efficient use at power plants.

\section{Description of the theoretical foundations of the methodology for designing and modernizing the flow-through parts of steam-turbine heating turbines. Statement of the research task}

At present, the methodology for designing and reconstructing the flow-through parts of the thermal steam turbines (TST) is based on the results of theoretical and experimental studies carried out at RTI, MPEI and LMF aimed at developing optimal designs and thermal schemes for multi-stage steam turbines operating in variable modes under different laws distribution of external loads $[4,5]$.

In the numerical realization of the methods $[4,5]$, special attention should be paid to the identification of the effects of losses of specific kinetic energy and the specific internal energy of the working substance (vapor) flow, and the calculation of the energy consumption coefficients in the flowing part of the turbine stages of various modifications. The theoretical basis of these methods is the classical theory of hydrodynamic flow (based on the law of conservation of energy in mechanical form), taking into account the loss of enthalpy due to various types of mechanical friction, viscosity and distortion of the geometric shape of the flow channel [5]. One-dimensional and two-dimensional schemes of mathematical modeling in the design and construction of flow parts of turbine stages [9] are effective and sufficiently reliable in this respect, which is actual, including for the development of numerical optimization methods for reconstruction and for conducting thermal and electrical tests of the functional equipment for steam turbine installations [10].

The practical importance of this area of research is determined by the fact that in the conditions of the modern market of electric and thermal energy, there are increased requirements to the indicators of reliability and efficiency of heat exchanging and generating equipment of TPSs [9]. Powerful (100-250 MW) heating turbines are subject to additional requirements due to the need for prolonged operation of the turbines during the heating period without a stop [10].

As the operating experience shows, each turbine size in a number of units has design flaws, the elimination of which could significantly improve their reliability. In addition, since the commissioning of turbines, new developments have appeared, the application of which could also significantly improve the reliability and economy of the units already in operation $[11,12]$.

The choice of the optimal design profile, geometric and physical (kinematic, hydrodynamic and thermophysical) parameters of the flow part of a multi-stage steam turbine is expediently represented as a set of numerical solutions of direct and inverse problems, based on modern methods of thermodynamic and gas dynamic analysis of turbomachines and turbo-generators, over a wide range of values produced electric and thermal power. The defining value in the mathematical modeling of a one-dimensional problem should be reduced to an analytical study of the distribution functions of the thermotechnical and hydrodynamic parameters of the vapor along the radius at the exit from the scapular apparatus of an arbitrary stage, with given indices of activity and reactivity.

According to the main provisions of the one-dimensional model, the thermodynamic process of the flow of working substance (steam) moving in the direction of the axis of the turbine OX, on the elements of the modeled turbine stage, will be described by the laws of adiabatic (isentropic: $\delta s=0, s=$ const) expanding [13]: $v_{1}>v_{0},\left[\frac{\mathrm{m}^{3}}{\mathrm{~kg}}\right] ; t_{1}<t_{0},\left[{ }^{\circ} \mathrm{C}\right] ; p_{1}<p_{0}$, [Pa]. In this case, according to the Bernoulli law (the energy equation in the mechanical form) $i_{0}-i_{1}=\frac{c_{1}^{2}-c_{0}^{2}}{2},\left[\frac{\mathrm{J}}{\mathrm{kg}} \equiv \frac{\mathrm{m}^{2}}{\mathrm{~s}^{2}}\right]$, negative increment of the specific enthalpy of the stream $\Delta i=i_{1}-i_{0}<0$, where $i_{0}, i_{1}-$ respectively, the enthalpy at the inlet and outlet of the stage element, leads to a significant increase in the flow velocity at the outlet $c_{1}>c_{0},\left[\frac{\mathrm{m}}{\mathrm{s}}\right]$. 
The reliability of the calculation results is ensured by taking into account the loss of enthalpy of the flow on the nozzle blades (NB) $\Delta h_{s}=\frac{c_{1 t}^{2}-c_{1 f}^{2}}{2}=\left(1-\varphi^{2}\right) \frac{c_{1 t}^{2}}{2}$ and working blades $\Delta h_{\rho}=\frac{w_{2 t}^{2}-w_{2 f}^{2}}{2}=\left(1-\psi^{2}\right) \frac{w_{2 t}^{2}}{2}$, with the help of speed loss factors $\varphi=\frac{c_{1 f}}{c_{1 t}}, \psi=\frac{w_{2 f}}{w_{2 t}}$ [13], which are calculated at each step of the iteration. Additional losses are introduced «step by step». Typically, the theoretical flow rate $c_{1 \mathrm{t}}$ at the exit from the NB slightly higher than the actual speed $c_{1 f}$, which agrees with the results of calculations $\varphi \approx 0.95 \div 0.99$ [13]. For peripheral WB blades respectively $w_{2 f}<w_{2 t}, \psi \approx 0.97 \div 0.99$ [14]. The calculated value of the initial flow velocity at the inlet to the nozzle blades of the first stage of the model turbine is adopted in the range $c_{0}=200-250 \mathrm{~m} / \mathrm{s}$, depending on the values of the initial parameters of the vapor $\left\{p_{0} ; t_{0} ; v_{0} ; i_{0} ; s_{0}\right\}[13]$.

In calculating the technical characteristics of the stages and the flow part, along with analytical expressions (direct consequences of fundamental thermodynamic and hydrodynamic equations), semiempirical relationships derived from experimental and production tests on individual elements of the flow part (profiles, blades, compaction, etc.) are actively used. To ensure the reliability of the modeled structure, additional numerical estimates of axial forces on the blades and disks, as well as stresses from centrifugal forces and flexural steam forces in the root of the blades and the shank, are necessary. The purpose of optimizing the parameters of the step along the radius $r$ is to select the rational law of twisting of the vane apparatus, which, given the boundary conditions, provides the maximum value of the relative blade efficiency of the step $\eta_{0, n}=1-\frac{\Delta h_{s}+\Delta h_{\rho}}{E_{0}}$, where $E_{0}=\frac{c_{0}^{2}}{2}$ - the specific energy of the flow at the entrance to the nozzle lattice of the stage $[13,14]$. The choice of the mathematical model assumes the calculation of averaged over the radius of the values of the variable parameters $\left\langle c_{1 t}^{2}\right\rangle=\frac{1}{R} \int_{0}^{R} c_{1 t}^{2}(r) d r,\left\langle w_{2 t}^{2}\right\rangle=\frac{1}{R} \int_{0}^{R} w_{2 t}^{2}(r) d r$, where $R-$ structural radius of the stage.

The structure of the one-dimensional model makes it possible to use the modification of the method of directional search for the optimal variant according to the coordinate descent scheme [15] in combination with the method of minimizing the comparison function (MCF-method) [6], which assumes the development of an algorithm for computer comparison of theoretical (calculated) and empirical (measured in the experiment) of the flow parameter values and the flow part of the stage. The restrictions are taken into account with the help of the penalty function, which ensures compliance with the requirements for these design features. The calculation is carried out sequentially from the first to the last step [11-13].

When developing a three-dimensional model of processes of working substance on the elements of the turbine stage, the design methodology of the turbine blade should be used [14], based on the delineation of the evaluation criteria for individual functional groups - reliability, aerodynamics, manufacturing technology, implemented by analogy with the MCF method, with the help of a special algorithm that makes up the theoretical basis of the corresponding software and hardware (a set of calculation programs). This software package should be versatile, since the presented system of interconnected algorithms provides the solution of tasks in terms of the optimal design, including when developing schemes for upgrading existing steam turbines with different levels of unification of their individual elements.

The aim of this paper is to describe the existing methods of theoretical analysis of processes of working substance (steam) and to develop schemes for numerical optimization of physical (thermodynamic, hydrodynamic, mechanical, etc.) and design parameters of turbine stages in a wide range of initial parameters of steam (temperature, pressure, entropy, enthalpy, specific volume) and loads of consumers. As a research object, we take the model steam turbine T-110-120-130 LMF, the modernization of which was partially considered in [12], where the verification thermal calculation and comparative numerical analysis of the characteristics of the turbine technological scheme before and after the modernization of the scraper apparatus of the MPC and LPC [12]. The influence of the shape of the blades on the integral parameters (power, efficiency, available heat dissipation) of the turbine in [12] has not been investigated. The subject of the research is to develop the basics of the physical and mathematical model and numerical optimization of the parameters of the flowing parts of steam turbines, in relation to the connected electrical loads and loads of heating systems. 
The research methodology will be constructed according to the known schemes for the modernization of the flow parts of cylinders and the operating modes of turbines of this class $[4,5]$, the theoretical foundations of the thermodynamic and hydrodynamic analysis of steam processes in the flowing part of the turbine stage and methods for numerical optimization of the parameters of the design technological schemes of installations and systems.

The methodology of mathematical modeling will be based on the method of minimizing the comparison function (MCF-method) [6], which, in combination with numerical methods for studying the properties of functions of many variables and the method of finite differences (for solving systems of equations of mathematical physics) [15], the optimal correspondence between theoretical (calculated) and measured (experimental) values of the characteristic parameters of the physical-mathematical model (PMM). Further, the results of the investigation of the basic equations and identities of the FMM models will be used to form the technological models (TM) of power plants and systems including separate subsystems (functional elements) described with the help of the corresponding optimized numerical values of the PMM model parameters, which determines the applied scientific significance of the proposed research topic. The scientific novelty of this direction is reduced to the development and practical adaptation of innovative methods for designing and modernizing the flow parts of steam turbines based on the use of generalized schemes for theoretical and experimental study of nonlinear processes of a working substance, in combination with methods for numerical optimization of the performance of individual functional elements and the entire steam turbine plant as a whole.

\section{Calculation substantiation of the modernization of the flow-through parts of the heat-recovery steam turbine T-110-120-130 LMF}

In continuation of the works $[11,12]$, based on the methodology proposed by the MPEI, based on the schemes of numerical thermal calculation, we will carry out detailed studies of the variants of modernization of the flowing part of the turbine T-110-120-130 LMF. The technological scheme of the turbine of this model is shown in Figure 1 (according to [16]), the basic thermal scheme (BTS) - in Figure 2 (according to [16]), where HPC (stages No. 1-9) is countercurrent and has 1 regenerative (unregulated) the selection of steam, for the 9th stage, at HPH-3. The MPC (stages No. 10-23) has two regenerative steam selections for HPH-2 and HPH-1, respectively, for the 11th and 14th stages. Regulated (heating) steam samplings for heaters HNH-2, LPH-2 (upper selection) and HNH-1, LPH-1 (lower selection) are provided on the central heating tower from the 21st and 23rd stages. The fourth one is unregulated selection for the 17th stage, for the LPH-4, the fifth one is unregulated for the 19th stage, for the LPH-3. The LPC is a two-flow stage (stages No. 24-27), one speed and pressure.

Technical characteristics of the turbine T-110-120-130 LMF are given in Table 1.

Table 1

Rated technical characteristics of the turbine unit T-110-120-130 LMF

\begin{tabular}{|l|l|}
\hline Rated power & $110 \mathrm{MW}$ \\
\hline Max power & $120 \mathrm{MW}$ \\
\hline Parameters of «fresh» steam & $p_{0}=12.75 \mathrm{MPa} ; t_{0}=555^{\circ} \mathrm{C}$ \\
\hline Final pressure & $p_{C}=12.75 \mathrm{kPa}$ \\
\hline Maximum steam consumption (through HPC) & $G_{H P C, \max }=485 \mathrm{t} / \mathrm{h}$ \\
\hline Minimum steam consumption (through LPC) & $G_{L P C, \min }=18 \mathrm{t} / \mathrm{h}$ \\
\hline Rotation frequency & $3000 \mathrm{rpm}$ \\
\hline Pressure in the upper selection & $p_{1}=6025 \mathrm{kPa}$ \\
\hline Pressure in the bottom selection & $p_{2}=5020 \mathrm{kPa}$ \\
\hline Mechanical efficiency of the turbine & 0,99 \\
\hline Maximum vapor transmission to the condenser & $G_{C, \max }=280 \mathrm{t} / \mathrm{h}$ \\
\hline
\end{tabular}




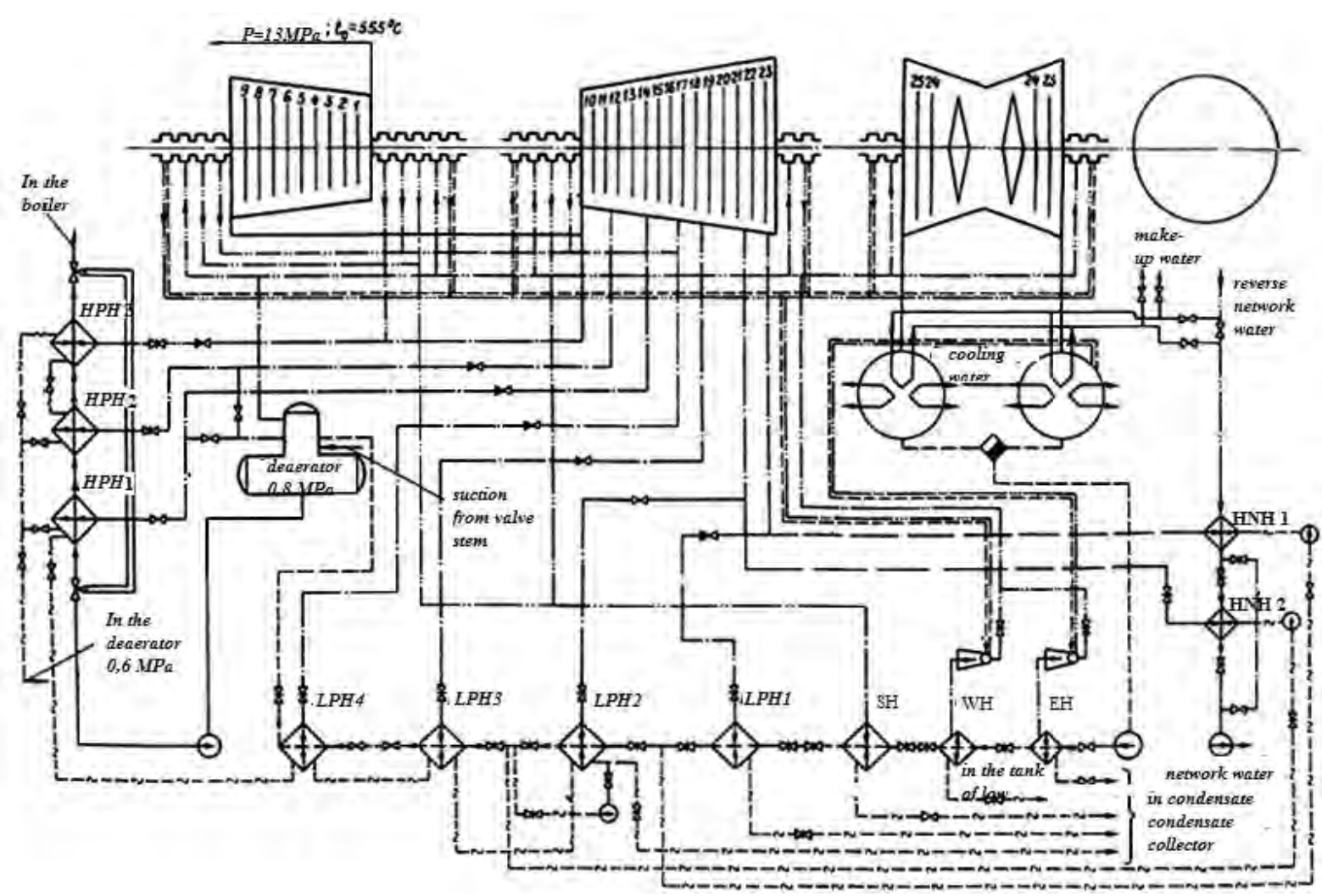

$\mathrm{HPH}$ — high pressure heaters (3 heaters); $\mathrm{LPH}$ - low pressure heaters (4 heaters);

$H N H-1,2$ - horizontal network heaters; $S H$ - Stuffing heater; $W H$ - water heater; $E H$ - Ejector heater

Figure 1. Technological scheme of the steam turbine installation T-110-120-130 LMF

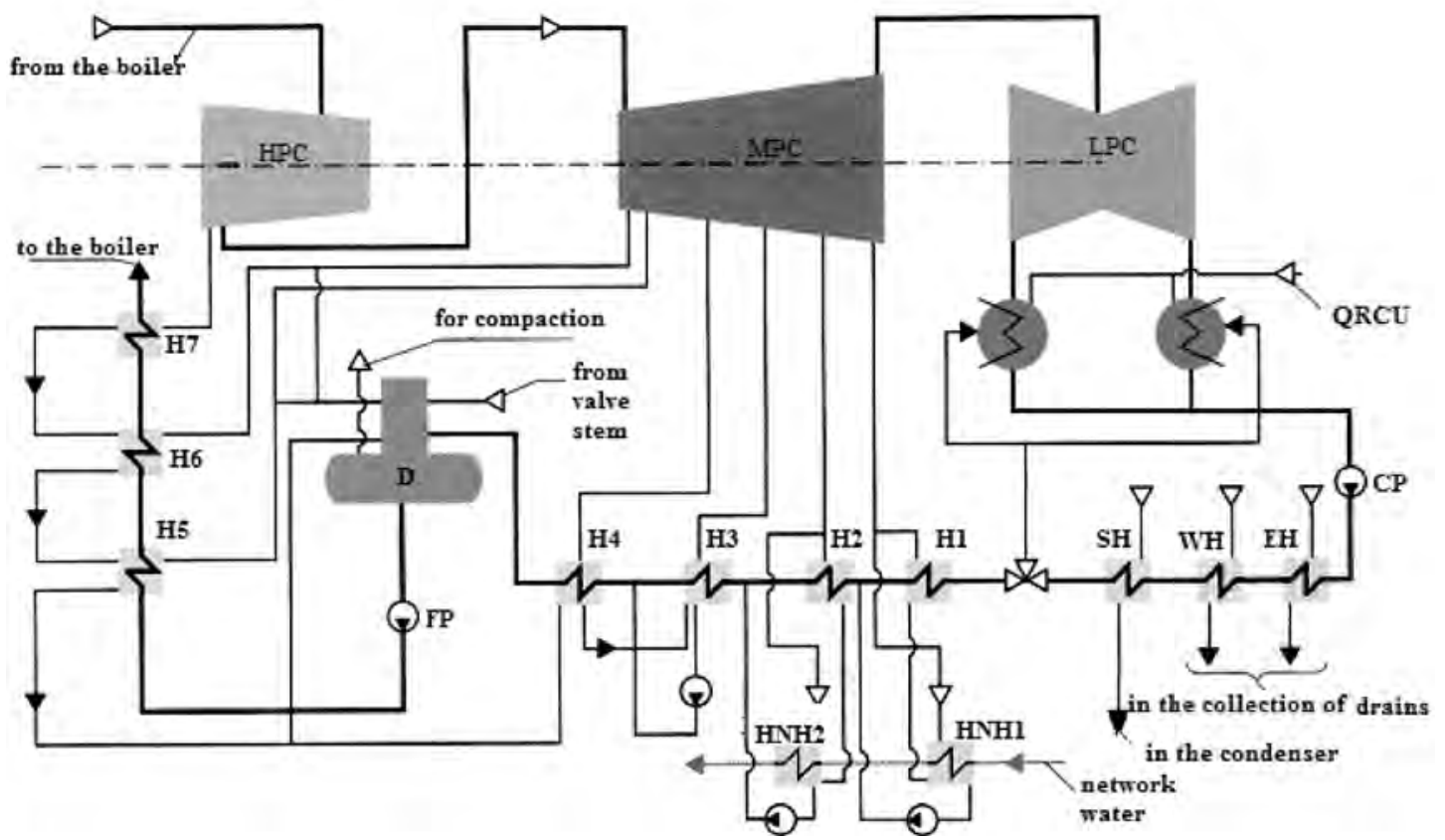

HPC — high pressure cylinder; $M P C$ - medium pressure cylinder; LPC — low pressure cylinder; $\mathrm{HNH}$-1, 2 - horizontal network heaters; $\mathrm{H1}-\mathrm{H} 4$ - low pressure heaters (LPH);

H5-H7 — high pressure heaters (HPH); QRCU — Quick-acting reduction-cooling units; D — deaerator; SH - Stuffing heater; $W H$ - water heater; $E H$ - Ejector heater; $C P$ — condensate pump; FP — feed pump

Figure 2. Principal thermal scheme of the turbine T-110-120-130-5 LMF 
The detailed analysis of the numerical calculations in this work consists in the study of: 1) an additional variant of turbine reconstruction, by replacing the working blades of stages No. 24, 25 (by analogy with steps No. 26, 27 [12]) on the blades of the saber-shaped form (Fig. 3); 2) Influences of enthalpy (heat-drop) incremental losses of stages No. 21, 22, 24-27 on the turbine efficiency, by the method of successive approximations, by expanding the model functions $\Delta h_{s}\left(\left\langle c_{1 t}^{2}\right\rangle ; t\right), \Delta h_{\rho}\left(\left\langle w_{2 t}^{2}\right\rangle ; t\right), \eta_{0, n}\left(\left\langle c_{1 t}^{2}\right\rangle ;\left\langle w_{2 t}^{2}\right\rangle ; t\right)$ in power series with respect to dimensionless comparison parameters $\varphi=\frac{c_{1 f}}{c_{1 t}}<1, \psi=\frac{w_{2 f}}{w_{2 t}}<1$, having the meaning of perturbation theory parameters; 3) Theoretical temperature graph of heating systems 150/70. In [12], the calculated temperature profile of the heating network was assumed to be 140/70.
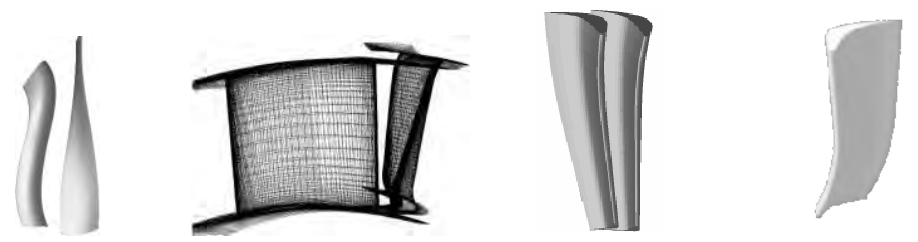

Figure 3. Different shapes of the profiles of the scapula

The main object of modernization, in this work, is a heating plant (HP) including network heaters (boilers) such as HNH (horizontal network heaters) [16]: HNH-2 works to heat the network water (coming from the return pipeline of the heating network) energy «removed» from the «top» heating selection (from the 21st stage), and cooled at the NHH-2 steam, then goes to the LPH-2, where it works to heat the feed water; at $\mathrm{NHH}-1$, the enthalpy of steam «removed» from the «lower» heating stage (from the 23rd stage) is used to heat the network water, and the steam cooled at the HNH-1 steam, then goes to the LPH-1, included in the complex with the LPH-2, into a single scheme of regenerative sampling (4LPH + 3HPH + deaerator) from the turbine T-110-120-130 LMF. Schematic diagram of the connection of heating equipment in the technological scheme of the turbine is shown in Figure 4.

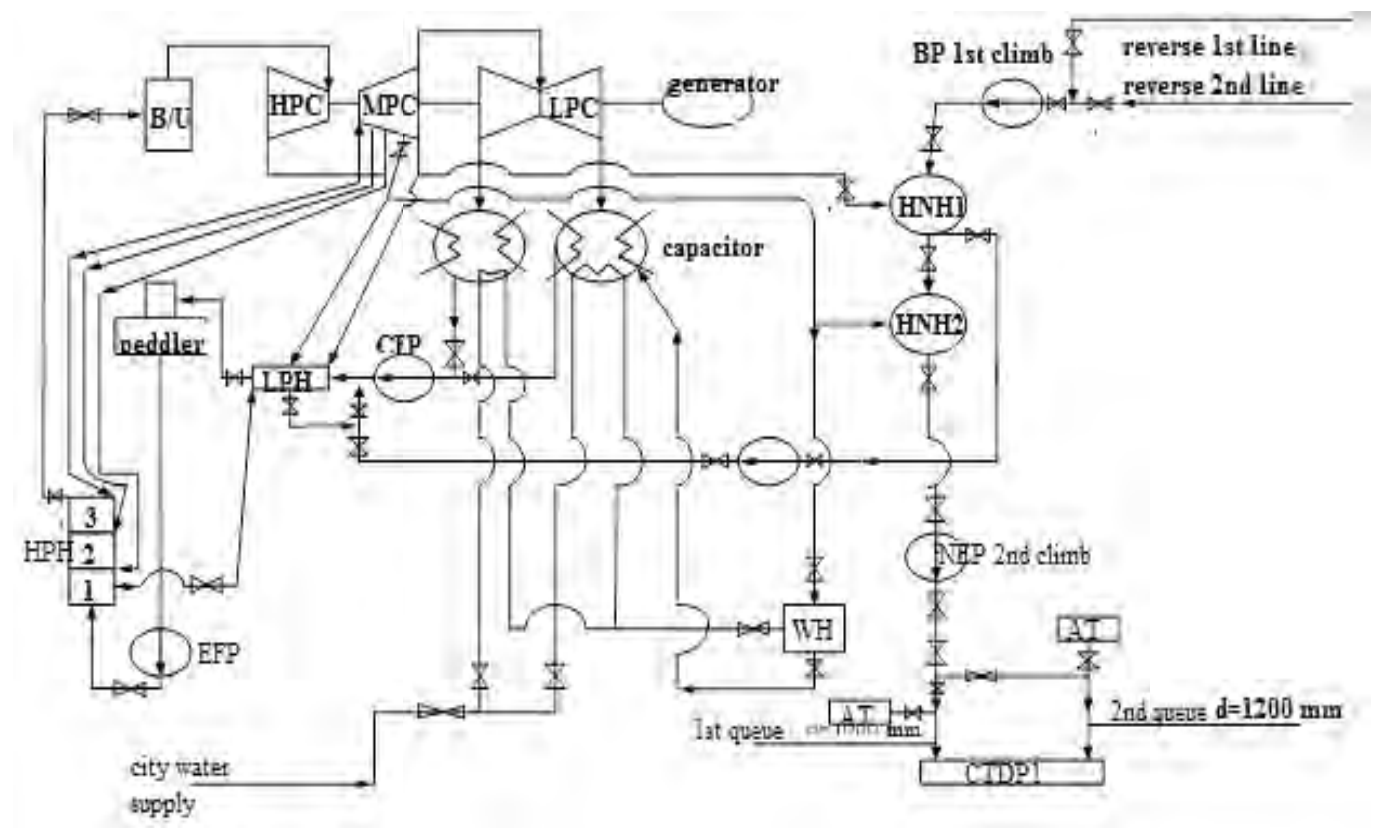

CTDP-1 — central thermal distribution point; $B / U$ - boiler unit; HPC — high-pressure cylinder; $M P C$ - medium pressure cylinder; $L P C$ - low-pressure cylinder; $B P$ - first lift booster pumps;

$H N H$-1, 2 - horizontal network heaters; CEP — condensate electric pump; $L P H$ - low pressure heater (4 preheaters); $H P H$ - high pressure heaters (3 preheaters); EFP — electric feed pump; $W H$ - water heater; $N E P$ — second-line network electric pumps; $A T$ - accumulator tanks

Figure 4. Schematic diagram of the connection of the heating equipment of KarTPS-3 
We accept the nominal operating mode of the turbine (power - $110 \mathrm{MW}$ ), with the initial parameters of the steam: 12.7 MPa; [12]. The theoretical (calculated) steam flow to the turbine is $380 \mathrm{t} / \mathrm{h}$ [12].

Based on the results of numerical calculations, the reconstruction of stages No. 24-27 (LPC) leads to an increase in the relative internal efficiency of each of the steps by $8-10 \%$ and their internal power by 10-15 MW. At the same time, the estimated value of the deficit in the thermal capacity of the turbine (the difference in the connected and available capacity of the heating plant, per turbine) remains practically unchanged, in comparison with the actual value of this parameter (measured by the testimony instruments) [12]. Thus, the reconstruction of the LPC blading apparatus has practically no effect on the performance of network heaters $(\mathrm{HNH}-1,2)$ and the parameters of the network water. At the same time, the efficiency of the turbine increases by 0.12 .

Reconstruction of nozzle blades of stages No. 21, 23 (MPC), from which regulated (heating) steam samplings are carried out for heating the network water (Fig. 4), gives an insignificant increase in the relative internal efficiency of these steps (as a rule, by 2-3\%) and their the internal capacity is 1-2 MW. At the same time, the design capacity of the heating plant increases by 10-12 Gcal/h, and the deficit of the thermal power of the turbine is reduced by $15-20 \mathrm{Gcal} / \mathrm{h}$, which, according to the actual temperature schedule of the heat network, 140/70, corresponds to the heat load of the average five-story residential building. Then, under the conditions of the «Karaganda Thermal Power Station-3», the reconstruction of the turbine blades of turbines No. $1-4$, reduces the deficit of the thermal capacity of the station by approximately $60-80 \mathrm{Gcal} / \mathrm{h}$. Additional reconstruction of the stages with heating runs for two turbines T-120-140-130 LMF, in total leads to an increase in the available thermal capacity of the station by $90-120 \mathrm{Gcal} / \mathrm{h}$.

The calculations were carried out in relation to the actual connected loads of the heating systems, in the conditions of the station «Karagandinskaya TPS-3» [17], as of January 1, 2018.

\section{Nonlinear effects on elements of the modernized turbine T-110-120-130 LMF}

Based on the results of detailed numerical calculations of the turbine T-110-120-130 LMF, nonlinear effects are observed on the model nozzle blades of the saber-like shape, in contrast to the existing (linear) hydrodynamic model, which, according to Figure 5, appear as a nonlinear dependence of the calculated relative internal efficiency stage of steam pressure in the upper heating stage $p_{S}^{\text {HTS }}$, MPa. Presence, with the initial values of the steam parameters $p_{0}=12.75 \mathrm{MPa} ; t_{0}=555^{\circ} \mathrm{C}$, theoretical maximum of the function $\eta_{0 i}\left(p_{m}^{u}\right)$ at the point $(0.758 ; 0.07)$ indicates the determining role of nonlinear hydrodynamic processes of steam on the steps with heating selections.

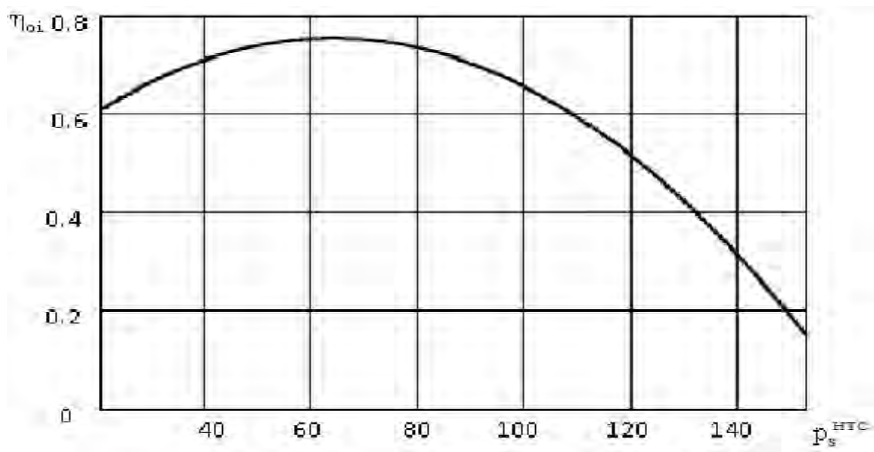

Figure 5. Dependence of the relative internal efficiency of the turbine T-110-120-130 LMF, on the pressure in the upper heating system (station No. 21 (MPC))

The linear model of the hydrodynamic flow, for the turbine T-110-120-130 LMF, gives a monotonically decreasing function of the internal relative efficiency from the pressure in the selection in the range 0-0.14 MPa [13].

\section{Indicators of economic efficiency}

Calculation of indicators of technical and economic efficiency of design solutions (Table 2) gives a payback period of the project - 1.5 years, with profitability $-80 \%$. The calculation was carried out for the enterprise «Karagandinskaya TPS-3» [18], at prices (in tenge), as of January 1, 2018. 
Technical and economic parameters of the reconstruction of the flowing part of the turbine T-110-120-130 LMF

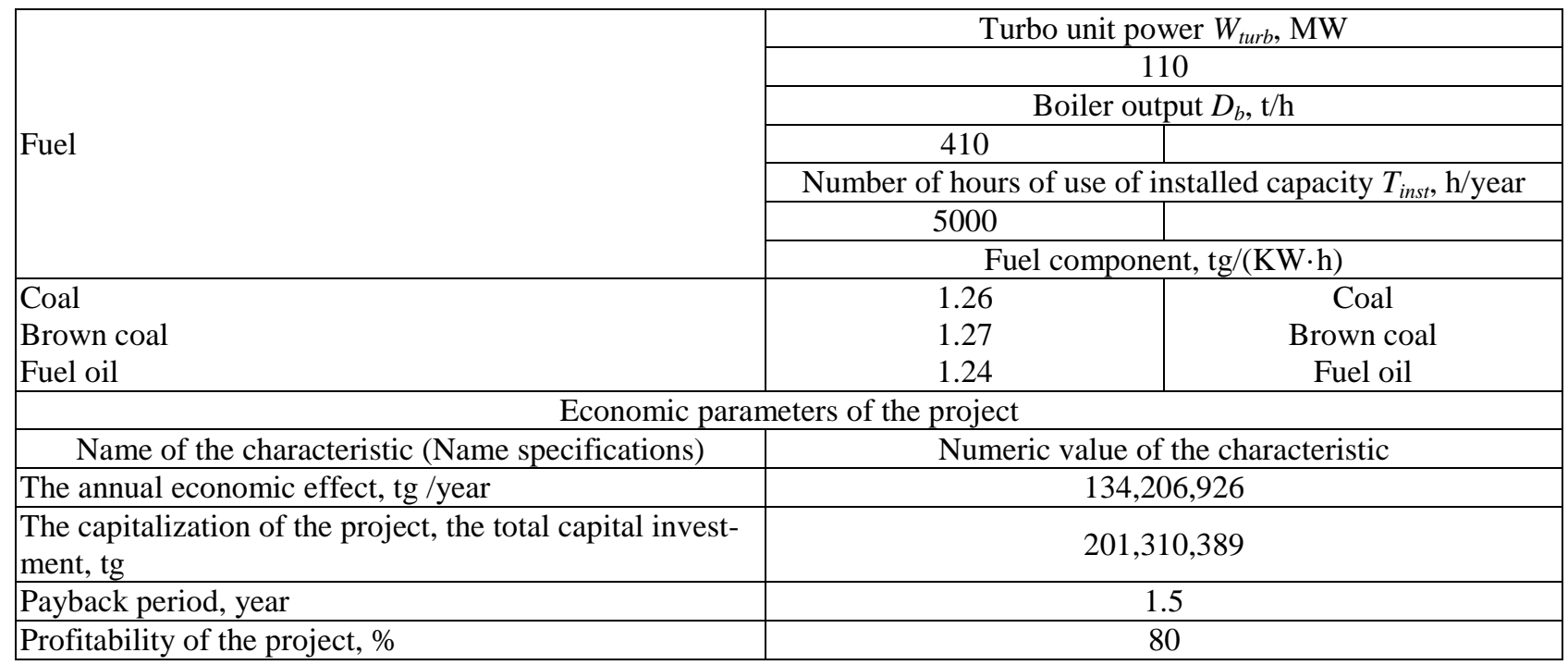

The described schemes for the numerical calculation of the parameters of flow parts (MLPC, LPC) of the modernized turbine T-110-120-130 LMF can be considered as basic, taking into account certain features of the production and economic situation determined by the specific functioning of this specific thermal power plant, with installed turbines of this model.

It is obvious that the methodology proposed in the work, taking into account the corresponding amendments to the technological schemes, can be applied to the numerical optimization of the operation parameters of a number of turbines of the class of thermal steam turbines of medium (100-150 MW) and high (150$250 \mathrm{MW})[14]$.

\section{References}

1 Петреня Ю.К. Современные методы создания и модернизации паровых турбин для технического перевооружения электростанций / Ю.К. Петреня, В.Д. Гаев // Энергетика - экология - энергосбережение: тез. докл. науч.-практ. конф. (16-18 мая 2016 г.). - Калуга, 2016. - С. 157-159.

2 Балабанович В.К. Совершенствование схем и режимов работы теплофикационных паротурбинных установок / В.К. Балабанович. — Минск: Полибиг, 2000. — 188 с.

3 Petrenya Yu.K. Modern methods for constructing and modernizing flow-through parts of steam turbines / Yu.K. Petrenya, V.D. Gaev // Power technology and engineering. — 2017. — Vol. 50, No. 6. - P. 625-628.

4 Melnikov A.V. Modernization of the 300 MW power generating units at the Konakovo state regional electric power plant / A.V. Melnikov, G.D. Avrutsky, V.D. Gaev // Power Technology and Engineering. - 2013. — Vol. 46, No. 5. - P. $387-391$.

5 Конюшин М.В. О выборе оптимального варианта модернизации паровых турбин / М.В. Конюшин // Неделя науки СПбГПУ. Институт энергетики и транспортных систем: материалы науч.-практ. конф. - СПб., 2014. - Ч. 2. — С. $136-138$.

6 Kalytka V.A. The scheme of numerical optimization of the parameters of electrophysical processings in heterogeneuos solid elements / V.A. Kalytka, M.V. Korovkin, A.I. Aliferov, A.V. Bashirov, D.R. Talaspekov // Вестн. Караганд. ун-та. Сер. Физика. - 2018. - № 2(90). - С. 34-42.

7 Симою Л.Л. Эффективность модернизации цилиндра низкого давления турбины Т-185-220-12,8 / Л.Л. Симою, Г.Д. Баринберг, Е.И. Эфрос, В.В. Ермолаев, Л.А. Жученко, А.И. Шкляр, Ю.А. Сахнин, С.Н. Моденов, Б.Б. Калинин // Теплоэнергетика. - 2007. — № 4. - С. 32-37.

8 Моденов С.Н. Нормализация тепловых расширений теплофикационных турбин на Омской ТЭЦ-5 / С.Н. Моденов, Б.Е. Мурманский, Ю.М. Бродов, А.И. Лепяцкий, А.Ю. Сосновский, В.В. Ермолаев // Электрические станции. - 2010. № 8. - С. 47-51.

9 Марков К.Я. Новые способы охлаждения ЦНД мощных теплофикационных турбин / К.Я. Марков, В.И. Кузьмина // Экспресс-информация. Опыт ПО ТМЗ в паротурбостроении. - М., 1975. — Вып. 1. - С. 14-17.

10 Балабинович В.К. Расчетный метод сравнения конструкций проточной части турбомашин / В.К. Балабинович, Н.Б. Карницкий, В.М. Неуймин, И.П. Усачев // Энергетика: Известия высших учебных заведений и энергетических объединений СНГ. - 1996. — № 5-6. - С. 77-82. 
11 Калытка В.А. Анализ технологической схемы работы автоматизированной турбины в режиме синхронного компенсатора / В.А. Калытка, А.В. Баширов, Ф.Н. Булатбаев, Т.А. Ханов, Б.С. Оспанов, Е. Божбанов // Вестн. Караганд. ун-та. Сер. Физика. — 2017. - № 4(88). - С. 41-46.

12 Калытка В.А. Методы повышения показателей тепловой экономичности и надежности теплофикационных турбин / В.А. Калытка, А.В. Баширов, А.Д. Мехтиев, Т.А. Ханов, Б.С. Оспанов, С.Б. Тусупбаев // Вестн. Караганд. ун-та. Сер. Физика. — 2017. — № 4(88). - С. 47-52.

13 Калытка В.А. Турбины тепловых и атомных электростанций: учеб. пособие / В.А. Калытка. - Караганда: МБА, 2011. - $158 \mathrm{c}$.

14 Трухний А.Д. Стационарные паровые турбины. - 2-е изд., перераб. и доп. / А.Д. Трухний. — М.: Энергоатомиздат, 1990. - 640 c.

15 Калиткин Н.Н. Численные методы / Н.Н. Калиткин. - М.: Наука, 1978. - 512 с.

16 Инструкции по эксплуатации оборудования ТЦ КарТЭЦ-3. - 2013. — 583 с.

17 Отчет турбинного цеха КарТЭЦ-3 за отопительный сезон 2017-2018 гг. — 2018. — 152 с.

18 Отчет производственно-технического отдела КарТЭЦ-З за отопительный сезон 2017-2018 гг. — 2018. — 83 с.

\title{
В.А. Калытка, М.В. Коровкин, А.И. Алиферов, А.В. Баширов, Т.А. Ханов, Д.Р. Таласпеков
}

\section{Жылуландыру бу турбиналарының ағынды бөліктерін жаңғырту әдістерінің теориялық негіздері}

\begin{abstract}
Жылу желілерінің теориялық температуралық графигіне және тұтынушылардың қосылған жүктемелерінің есебінде, жұмыстың номиналды режимінде жылуландыру бу турбиналарының технологиялық сұлбаларын жобалау және жаңғырту әдістемесінің теориялық негіздері қарастырылған. Турбиналық сатының параметрлерін сандық оңтайландырудың базалық әдісі ретінде саты элементтері арқылы қозғалатын жұмыс заты (бу) процестерінің техникалық сипаттамаларының теориялық және эксперименттік мәндерінің арақатынасын көрсететін көпөлшемді функционалдың минимум нүктелерін іздестіруге негізделген салыстыру функциясын азайту әдісі (СФА-әдісі) қабылданды. Зерттелетін процестердің математикалық моделін құру гидродинамикалық ағынның сызықсыз бір- және екіөлшемді теңдеулерінің және жылуөткізгіштік теңдеулерінің негізінде, технологиялық схеманың әртүрлі учаскелерінде энтальпия өсуінің жоғалуын есепке ала отырып, жүргізілді. Зерттеу нысаны ретінде «Қарағанды ЖЭО-З» станциясы жағдайында номиналды параметрлерде (110 МВт) жұмыс істейтін Т-110-120-130 модельді ЖМЗ жылуфикациялық бу турбинасы қабылданды. Жаңғырту нысаны ТҚЦ және ОҚЦ сатылары тобының жұмыс қалақтарын қылыш пішінді қалақшаларға ауыстырудан тұрады. Толық сандық есептеулердің нәтижелері бойынша, ОҚЦ сатыларын қайта жаңарту турбинаның есептік жылу куатын 10-12 Гкал/сағ және барлық станцияны 90-120 Гкал/сағ ұлғайтуды береді, бұл ЖЭС технологиялық сұлбаларын қайта жаңарту жоспарларын әзірлеу кезінде белгілі практикалық мәнге ие. Қылыш тәрізді формадағы модельді қалақшаларда теориялық түрде жоғарғы жылыту іріктеуіндегі бу қысымынан есептік салыстырмалы ішкі ПӘК сатысының желілік емес тәуелділігі түрінде көрінетін сызықты емес гидродинамикалық әсерлер орнатылған.
\end{abstract}

Кілт сөздер: жылуландыру бу турбинасы, принциптік жылу схемасы, жоғары, орташа және төмен қысымды цилиндрлер, турбиналық сатының салыстырмалы ішкі ПӘК, турбинаның қолда бар жылу қуаты, қылыш тәрізді қалақтар, сызықты емес гидродинамикалық әсерлер.

\section{В.А. Калытка, М.В. Коровкин, А.И. Алиферов, А.В. Баширов, Т.А. Ханов, Д.Р. Таласпеков}

\section{Теоретические основы методов модернизации проточных частей теплофикационных паровых турбин}

\begin{abstract}
Рассмотрены теоретические основы методологии проектирования и модернизации технологических схем теплофикационных паровых турбин в номинальном режиме работы, в расчете на теоретический температурный график теплосетей и присоединенные нагрузки потребителей. В качестве базового метода численной оптимизации параметров турбинной ступени принимается метод минимизации функции сравнения, основанный на поиске точек минимума многомерного функционала, отражающего соотношения теоретических и экспериментальных значений технических характеристик процессов рабочего вещества (пара), двигающегося через элементы ступени. Построение математической модели исследуемых процессов проводится на основании нелинейных одномерных и двумерных уравнений гидродинамического потока и уравнений теплопроводности, с учетом потерь приращений энтальпии на различных участках технологической схемы. В качестве объекта исследования принята теплофикационная паровая турбина модели Т-110-120-130 ЛМ3, работающая на номинальных параметрах (110 МВт) в условиях станции «Карагандинская ТЭЦ-З». Предмет модернизации состоит в замене рабочих
\end{abstract}


лопаток группы ступеней ЦНД и ЦСД на лопатки саблевидной формы. По результатам детальных численных расчетов реконструкция ступеней ЦСД дает увеличение расчетной тепловой мощности турбины на 10-12 Гкал/ч и всей станции на 90-120 Гкал/ч, что имеет определенную практическую значимость при разработке планов реновации технологических схем ТЭС. На модельных лопатках саблевидной формы теоретически установлены нелинейные гидродинамические эффекты, проявляющиеся в виде нелинейной зависимости расчетного относительного внутреннего КПД ступени от давления пара в верхнем отопительном отборе.

Ключевые слова: теплофикационная паровая турбина (ТПТУ); принципиальная тепловая схема (ПТС); цилиндры высокого (ЦВД), среднего (ЦСД) и низкого (ЦНД) давления; относительный внутренний КПД турбинной ступени; располагаемая тепловая мощность турбины; лопатки саблевидной формы; нелинейные гидродинамические эффекты.

\section{References}

1 Petrenya, Yu.K., \& Gaev, V.D. (2016). Sovremennye metody sozdaniia i modernizatsii parovykh turbin dlia tekhnicheskoho perevooruzheniia elektrostantsii [Modern methods of creating and modernizing steam turbines for the technical re-equipment of power plants]. Proceedings from Energy - Ecology - Energy Saving. Nauchno-prakticheskaia konferentsiia - Scientific-practical conference (pp. 157-159). Kaluga [in Russian].

2 Balabinovich, V.K. (2000). Sovershenstvovanie skhem i rezhimov raboty teplofikatsionnykh paroturbinnikh ustanovok [Improvement of schemes and operating modes of thermal steam turbine units]. Minsk: Polibig [in Russian].

3 Petrenya, Yu.K., \& Gaev, V.D. (2017). Modern methods for constructing and modernizing flow-through parts of steam turbines. Power Technology and Engineering, 50(6), 625-628.

4 Melnikov, A.V., Avrutsky, G.D., \& Gaev, V.D. (2013). Modernization of the 300 MW power generating units at the Konakovo State Regional Electric Power Plant. Power Technology and Engineering, 46(5), 387-391.

5 Konyushin, M.V. O vybore optimalnoho varianta modernizatsii parovykh turbin [On the choice of the optimal variant for the modernization of steam turbines]. Proceedings from Week of Science of SPbSPU. Institute of Energy and Transport Systems. Nauchno-prakticheskaia konferentsiia - Scientific-practical conference (Pt. 2, pp. 136-138) [in Russian].

6 Kalytka, V.A., Korovkin, M.V., Aliferov, A.I., Bashirov, A.V., \& Talaspekov, D.R. (2018). The scheme of numerical optimization of the parameters of electrophysical processings in heterogeneuos solid elements]. Vestnik Karahandinskoho Universiteta. Series Physics - Bulletin of Karaganda University. Seriia Fizika, 2(90), 34-42.

7 Simoyu, L.L., Barinberg, G.D., Efros, E.I., Ermolaev, V.V., Zhuchenko, L.A., \& Shklyar, A.I., et al. (2007). Effektivnost modernizatsii tsilindra nizkoho davleniia turbiny T-185-220-12,8 [Efficiency of modernization of the cylinder of low pressure of the turbine T-185-220-12,8]. Teploenerhetika - Heat power engineering, 4, 32-37 [in Russian].

8 Modenov, S.N., Murmansky, B.E., Brodov, Yu.M., Lepyatsky, A.I., Sosnovsky, A.Yu., \& Ermolaev, V.V. (2010). Normalizatsiia teplovykh rasshirenii teplofikatsionnykh turbin na Omskoi TETS-5 [Normalization of thermal expansion of heating turbines at Omsk TPP-5]. Elektricheskie stantsii - Electric stations, 8, 47-51 [in Russian].

9 Markov, K.Ya., \& Kuzmina, V.I. (1975). Novye sposoby okhlazhdeniia TSND moshchnykh teplofikatsionnykh turbin [New ways to cool the LPCs of powerful heating turbines]. Ekspress-informatsiia. Opyt PO TMZ v paroturbostroenii - Express information. Experience of TMZ in steam turbine construction, 1, 14-17 [in Russian].

10 Balabinovich, V.K., Karnitsky, N.B., Neuimin, V.M., \& Usachev, I.P. (1996). Raschetnyi metod sravneniia konstruktsii protochnoi chasti turbomashin [Calculation method for comparing the designs of the flowing part of turbomachines]. Enerhetika (Izvestiia vysshikh uchebnykh zavedenii i enerheticheskikh assotsiatsii SNG - Energy (News of higher educational institutions and energy associations of the CIS), 5-6, 77-82 [in Russian].

11 Kalytka, V.A., Bashirov, A.V., Bulatbaev, F.N., Khanov, T.A., Ospanov, B.S., \& Bozhbanov, E. (2017). Analiz tekhnolohicheskoi skhemy raboty avtomatizirovannoi turbiny $\mathrm{v}$ rezhime sinkhronnoho kompensatora [Analysis of the technological scheme of operation of an automated turbine in synchronous compensator mode]. Vestnik Karahandinskoho universiteta. Seriia Fizika - Bulletin of Karaganda University. Series Physics, 4(88), 41-46 [in Russian].

12 Kalytka, V.A., Bashirov, A.V., Mekhtiev, A.D., Khanov, T.A., Ospanov, B.S., \& Tusupbaev, S.B. (2017). Metody povysheniia pokazatelei teplovoi ekonomichnosti i nadezhnosti teplofikatsionnykh turbin [Methods of increasing the indicators of thermal efficiency and reliability of heating turbines]. Vestnik Karahandinskoho universiteta. Seriia Fizika - Bulletin of Karaganda University. Series Physics, 4(88), 47-52 [in Russian].

13 Kalytka, V.A. (2011). Turbiny teplovykh i atomnykh elektrostantsii [Turbines of thermal and nuclear power plants]. Karaganda: MBA [in Russian].

14 Trukhnii, A.D. (1990). Statsionarnye parovye turbiny [Stationary steam turbines]. (2nd Ed.). Moscow: Enerhoatomizdat [in Russian].

15 Kalitkin, N.N. (1978). Chislennye metody [Numerical methods]. Moscow: Nauka [in Russian].

16 Instruktsiia po ekspluatatsii oborudovaniia turbinnoho tsekha KarTETS-3 [Instruction for operation of the equipment of the turbine shop of Karaganda Cogeneration Plant-3], (2013) [in Russian].

17 Otchet turbinnoho tsekha KarTETS-3 za otopitelnyi sezon 2017-2018 hh. [Report of the turbine shop of Karaganda Cogeneration Plant-3 for the heating season 2017-2018], (2018) [in Russian].

18 Otchet proizvodstvenno-tekhnicheskoho otdela KarTETS-3 za otopitelnyi sezon 2017-2018 hh. [Report of the production and technical department of Karaganda Cogeneration Plant-3 for the heating season 2016-2017]. (2017) [in Russian]. 